Bull. Chem. Soc. Ethiop. 2020, 34(2), 313-321.

ISSN 1011-3924

(c) 2020 Chemical Society of Ethiopia and The Authors

Printed in Ethiopia

DOI: https://dx.doi.org/10.4314/bcse.v34i2.9

\title{
SYNTHESIS AND CHARACTERIZATION OF NOVEL FOUR HETERODIMETALLIC MIXED METAL COMPLEXES OF 2,6-PYRIDINEDICARBOXYLIC ACID
}

\author{
Halil İlkimen* and Rukiye Saygılı Canlıdinç \\ Department of Chemistry, Faculty of Arts and Sciences, Dumlupınar University, 43100 \\ Kütahya, Turkey
}

(Received July 4, 2019; Revised September 26, 2020; Accepted September 30, 2020)

\begin{abstract}
Four novel hetero dimetallic mixed metal complexes of 2,6-pyridinedicarboxylic acid $\left(\mathrm{H}_{2}\right.$ dipic $), \quad\left[\mathrm{Ni}\left(\mathrm{H}_{2} \mathrm{O}\right)_{5} \mathrm{Co}(\text { dipic })_{2}\right] \quad$ (1), $\quad\left[\mathrm{Co}\left(\mathrm{H}_{2} \mathrm{O}\right)_{5} \mathrm{Co}(\text { dipic })_{2}\right]\left[\mathrm{Ni}\left(\mathrm{H}_{2} \mathrm{O}\right)_{5} \mathrm{Ni}(\text { dipic })_{2}\right]\left[\mathrm{Co}(\right.$ dipic $\left.)\left(\mathrm{H}_{2} \mathrm{O}\right)_{3}\right] \quad$ (2), $\left[\mathrm{Cu}\left(\mathrm{H}_{2} \mathrm{O}\right)_{5} \mathrm{Ni}(\text { dipic })_{2}\right]_{2}\left[\mathrm{Co}(\mathrm{dipic})\left(\mathrm{H}_{2} \mathrm{O}\right)\right](3)$ and $\left[\mathrm{Ni}_{2}\left(\mathrm{H}_{2} \mathrm{O}\right)_{5} \mathrm{Cu}(\mathrm{dipic})_{2}\right]_{2}\left[\mathrm{Co}(\mathrm{dipic})\left(\mathrm{H}_{2} \mathrm{O}\right)\right]($ (4) have been prepared and characterized by elemental, AAS, spectral (IR and UV-Vis), and thermal analyses, as well as by using magnetic measurement and molar conductivity techniques. The results indicate that metal ions coordinate with 2,6-pyridinedicarboxylate ions ( $\mathrm{dipic}^{2-}$ ) nitrogen atoms and carboxylate oxygen atoms of ligands. The mole ratio of dipic ${ }^{2-}$ and metal ions in the complexes have been determined to be $2: 2(\mathrm{Co}, \mathrm{Ni})$ for $1,5: 5(3 \mathrm{Co}, 2 \mathrm{Ni})$ for $2,5: 5$ $(\mathrm{Co}, 2 \mathrm{Ni}$ and $2 \mathrm{Cu})$ for 3 and $5: 5(\mathrm{Co}, 2 \mathrm{Ni}$ and $2 \mathrm{Cu})$ for 4 according to the results of elemental analysis. The structures of 1-4 might be proposed as octahedral $\left(\left[\mathrm{Cu}(\right.\right.$ dipic $\left.)\left(\mathrm{H}_{2} \mathrm{O}\right)\right]$ unit for 2 square plane) according to results of spectroscopic analysis. The TG and DTA properties of compounds have been studied.
\end{abstract}

KEY WORDS: 2,6-Pyridinedicarboxylic acid, Mixed metal, Metal complex

\section{INTRODUCTION}

The metal complexes for pyridine-2,6-dicarboxylic acid (or dipicolinic acid, $\mathrm{H}_{2}$ dipic) and its deprotonated forms (Hdipic ${ }^{-}$and dipic $^{2-}$ ) show interesting structural features with various coordination modes [1], stabilization of unusual oxidation states [2] and insulin-mimetic effects $[3,4] . \mathrm{H}_{2} \mathrm{DPC}$ with $\mathrm{Cu}(\mathrm{II})$ ion commonly has one or two coordination modes [4]. In one coordination mode, a single planar DPC ligand associates in the equatorial plane of a metal cation with other ligands such as, $\mathrm{H}_{2} \mathrm{O}$ or pyridine-based heterocycles [4, 5], which occupy the remaining sites. This leads to the formation of square pyramidal $[4,6-10]$ or octahedral coordination geometry $[4,10-12,14]$. In the second coordination mode, two perpendicularly coordinated planar dipicolinic molecules generate distorted octahedral coordination geometry $[4,9,10,11]$.

Among the diversity of 2,6-pyridinedicarboxlate complexes known, there are several examples of homodimetallic $\left\{\left[\mathrm{M}\left(\mathrm{H}_{2} \mathrm{O}\right)_{5} \mathrm{M}(\text { dipic })_{2}\right] \cdot 2 \mathrm{H}_{2} \mathrm{O}(\mathrm{M}=\mathrm{Co}\right.$ [12-20], Ni [21] or $\mathrm{Cu}[22$, $23])\}$ and heterodimetallic $\left[\left\{\left[\mathrm{M}\left(\mathrm{H}_{2} \mathrm{O}\right)_{5} \mathrm{M}^{\prime}(\text { dipic })_{2}\right] \cdot \mathrm{mH}_{2} \mathrm{O}\left\{\mathrm{M} / \mathrm{M}^{\prime}=\mathrm{Cu}(\mathrm{II}) / \mathrm{Co}(\mathrm{II}), \mathrm{Cu}(\mathrm{II}) / \mathrm{Ni}(\mathrm{II})\right.\right.\right.$, $\mathrm{Cu}(\mathrm{II}) / \mathrm{Zn}$ (II), Zn(II)/Co(II), Ni(II)/Co(II) [24]; $\mathrm{Cu}(\mathrm{II}) / \mathrm{Ni}(\mathrm{II}), \mathrm{Cu}(\mathrm{II}) / \mathrm{Co}(\mathrm{II}), \mathrm{Cu}(\mathrm{II}) / \mathrm{Mn}$ (II) [25]; $\mathrm{Cu}(\mathrm{II}) / \mathrm{Co}$ (II), $\mathrm{Cu}$ (II)/Ni(II), $\mathrm{Cu}$ (II)/Zn(II) [26]; $\mathrm{Zn}$ (II)/Cu(II) [27]; $\mathrm{Cu}(\mathrm{II}) / \mathrm{Mn}$ (II) [28]; $\mathrm{m}=2$ or 3 \} aqua compounds of the types and with potential applications in fields of aqueous chemistry, catalysis, biochemistry, as water-soluble drugs, magnetic materials, in bleaching and bactericidal compositions [12-14, 17, 22, 24].

In this study, four novel homodimetallic mixed metal complexes of $\mathrm{H}_{2}$ dipic, $\left[\mathrm{Ni}\left(\mathrm{H}_{2} \mathrm{O}\right)_{5} \mathrm{Co}(\text { dipic })_{2}\right] \quad$ (1), $\quad\left[\mathrm{Co}\left(\mathrm{H}_{2} \mathrm{O}\right)_{5} \mathrm{Co}(\text { dipic })_{2}\right]\left[\mathrm{Ni}\left(\mathrm{H}_{2} \mathrm{O}\right)_{5} \mathrm{Ni}(\text { dipic })_{2}\right]\left[\mathrm{Co}(\right.$ dipic $\left.)\left(\mathrm{H}_{2} \mathrm{O}\right)_{3}\right] \quad$ (2), $\left[\mathrm{Cu}\left(\mathrm{H}_{2} \mathrm{O}\right)_{5} \mathrm{Ni}(\text { dipic })_{2}\right]_{2}\left[\mathrm{Co}\right.$ (dipic) $\left.\left(\mathrm{H}_{2} \mathrm{O}\right)\right](3)$ and $\left[\mathrm{Ni}\left(\mathrm{H}_{2} \mathrm{O}\right)_{5} \mathrm{Cu}(\text { dipic })_{2}\right]_{2}\left[\mathrm{Co}(\right.$ dipic $\left.)\left(\mathrm{H}_{2} \mathrm{O}\right)\right](4)$ have been prepared and characterized by elemental analysis (CHNS), AAS, spectral (IR and UVVis.), and thermal analyses, as well as by using magnetic measurement and molar conductivity techniques.

*Corresponding author. E-mail: halil.ilkimen@dpu.edu.tr

This work is licensed under the Creative Commons Attribution 4.0 International License 


\section{EXPERIMENTAL}

\section{General methods and materials}

All chemicals used were analytical reagents and were commercially purchased from Aldrich. Elemental analyses for $\mathrm{C}, \mathrm{H}$ and $\mathrm{N}$ were performed on Elementar Vario III EL and Co, Ni and $\mathrm{Cu}$ were detected with Perkin Elmer Optima 4300 DV ICP-OES. FT-IR spectra were recorded in the $4000-400 \mathrm{~cm}^{-1}$ region with Bruker Optics, Vertex 70 FT-IR spectrometer using ATR techniques. Thermal analyses were performed on Pelkin Elmer SII Exstar 6000 TG/DTA 6300 model using platinum crucible with $10 \mathrm{mg}$ sample. Measurements were taken in the static air within a $30-900{ }^{\circ} \mathrm{C}$ temperature range. The UV-Vis spectra were obtained for DMSO solution of the compounds $\left(10^{-3} \mathrm{M}\right)$ with a SHIMADZU UV-2550 spectrometer in the range of 200-900 $\mathrm{nm}$. Magnetic susceptibility measurements at room temperature were performed using a Sherwood Scientific Magway MSB MK1 model magnetic balance by the Gouy method using $\mathrm{Hg}\left[\mathrm{Co}(\mathrm{SCN})_{4}\right]$ as calibrant. The molar conductance of the compounds were determined in water/ethanol $(1: 1)$ and in DMSO $\left(10^{-3} \mathrm{M}\right)$ at room temperature using a WTW Cond $315 \mathrm{i} / \mathrm{SET}$ Model conductivity meter.

\section{Synthesis of 1-4}

A solution of $1 \mathrm{mmol}(0.249 \mathrm{~g}) \mathrm{Co}\left(\mathrm{CH}_{3} \mathrm{COO}\right)_{2} \cdot 4 \mathrm{H}_{2} \mathrm{O}$ and $2 \mathrm{mmol} \mathrm{H}_{2}$ dipic $(0.334 \mathrm{~g})$ in water (30 $\mathrm{mL}$ ) with stirring at room temperature for two hours was added dropwise to the solution of 1 mmol $(0.248 \mathrm{~g}) \mathrm{Ni}\left(\mathrm{CH}_{3} \mathrm{COO}\right)_{2} .4 \mathrm{H}_{2} \mathrm{O}$ in water $(20 \mathrm{~mL})$ with stirring at room temperature for two hours to complete the reaction. On filtration the reaction mixture, the solution was kept at room temperature for two weeks to give brown amorphous solid for $\mathbf{1}(0.377 \mathrm{~g}, 70 \%$ yield $)$.

A solution of $1 \mathrm{mmol}(0.248 \mathrm{~g}) \mathrm{Ni}\left(\mathrm{CH}_{3} \mathrm{COO}\right)_{2} \cdot 4 \mathrm{H}_{2} \mathrm{O}$ and $2 \mathrm{mmol} \mathrm{H}_{2}$ dipic $(0,334 \mathrm{~g})$ in water $(30 \mathrm{~mL})$ with stirring at room temperature for two hours was added dropwise to the solution of 1 mmol $(0.249 \mathrm{~g}) \mathrm{Co}\left(\mathrm{CH}_{3} \mathrm{COO}\right)_{2} \cdot 4 \mathrm{H}_{2} \mathrm{O}$ in water $(20 \mathrm{~mL})$ with stirring at room temperature for two hours to complete the reaction. On filtration the reaction mixture, the solution was kept at room temperature for two weeks to give brown amorphous solid for $2(0.266 \mathrm{~g}, 50 \%$ yield $)$.

A solution of $1 \mathrm{mmol}(0.248 \mathrm{~g}) \mathrm{Ni}\left(\mathrm{CH}_{3} \mathrm{COO}\right)_{2} .4 \mathrm{H}_{2} \mathrm{O}$ and $2 \mathrm{mmol} \mathrm{H}_{2}$ dipic $(0.334 \mathrm{~g})$ in water $(30 \mathrm{~mL})$ with stirring at room temperature for two hours was added dropwise to the solution of 1 mmol $(0.200 \mathrm{~g}) \mathrm{Cu}\left(\mathrm{CH}_{3} \mathrm{COO}\right)_{2} \cdot 2 \mathrm{H}_{2} \mathrm{O}$ in water $(20 \mathrm{~mL})$ with stirring at room temperature for two hours to complete the reaction. On filtration the reaction mixture, the solution was kept at room temperature for two weeks to give green amorphous solid for $3(0.346 \mathrm{~g}, 65 \%$ yield).

A solution of $1 \mathrm{mmol}(0.200 \mathrm{~g}) \mathrm{Cu}\left(\mathrm{CH}_{3} \mathrm{COO}\right)_{2} \cdot 2 \mathrm{H}_{2} \mathrm{O}$ and $2 \mathrm{mmol} \mathrm{H}_{2}$ dipic $(0.334 \mathrm{~g})$ in water $(30 \mathrm{~mL})$ with stirring at room temperature for two hours was added dropwise to the solution of 1 mmol $(0.248 \mathrm{~g}) \mathrm{Ni}\left(\mathrm{CH}_{3} \mathrm{COO}\right)_{2} \cdot 4 \mathrm{H}_{2} \mathrm{O}$ in water $(20 \mathrm{~mL})$ with stirring at room temperature for two hours to complete the reaction. On filtration the reaction mixture, the solution was kept at room temperature for two weeks to give turquoise amorphous solid for 4 ( $0.400 \mathrm{~g}, 75 \%$ yield $)$.

Suggested structures of the compounds (1-4) are shown in Figure 1.

Anal. calcd. for $1\left(\mathrm{C}_{14} \mathrm{H}_{16} \mathrm{CoN}_{2} \mathrm{NiO}_{13}\right)$ : C, 31.25\%; H, 3.02\%; Co, 10.98\%, N, 5.25\%; Ni, $10.85 \%$; found: $\mathrm{C}, 31.26 \%$; H, 3.00\%; Co, $10.96 \%, \mathrm{~N}, 5.21 \%$; $\mathrm{Ni}, 10.91 \%$; for 2 $\left(\mathrm{C}_{35} \mathrm{H}_{41} \mathrm{Co}_{3} \mathrm{~N}_{5} \mathrm{Ni}_{2} \mathrm{O}_{33}\right): \mathrm{C}, 31.03 \%$; H, 3.00\%; Co, $13.01 \%$, N, 5.21\%; Ni, 8.70\%; found: $\mathrm{C}$, $31.05 \%$; H, 3.05\%; Co, 13.06\%, N, 5.17\%; Ni, 8.67; for $3\left(\mathrm{C}_{35} \mathrm{H}_{37} \mathrm{Cu}_{3} \mathrm{~N}_{5} \mathrm{Ni}_{2} \mathrm{O}_{33}\right): \mathrm{C}, 31.55 \%$; $\mathrm{H}$, $2.80 \%$; Cu, $14.30 \%$, N, 5.25\%;Ni, 8.85\%; found: C, 31.57\%; H, 2.80\%; Cu, $14.32 \%, \mathrm{~N}, 5.26 \%$; $\mathrm{Ni}, 8.81$; for $4\left(\mathrm{C}_{35} \mathrm{H}_{37} \mathrm{Cu}_{3} \mathrm{~N}_{5} \mathrm{Ni}_{2} \mathrm{O}_{33}\right): \mathrm{C}, 31.56 \%$; H, 2.82\%; Cu, $14.35 \%$, N, 5.21\%; Ni, 8.80\%; found: $\mathrm{C}, 31.57 \%$; $\mathrm{H}, 2.80 \%$; $\mathrm{Cu}, 14.32 \%, \mathrm{~N}, 5.26 \%$; $\mathrm{Ni}, 8.81$. 


\section{RESULTS AND DISCUSSION}

The infrared spectral data of the starting compound $\left(\mathrm{H}_{2}\right.$ dipic) and compounds 1-4 are given in Table 1. In the high frequency region, weak bands $3067-3098 \mathrm{~cm}^{-1}$ are attributed to the stretching vibrations of aromatic $\mathrm{C}-\mathrm{H}$ for all compounds. There are also broad absorption bands at $3493-3474 \mathrm{~cm}^{-1}$, which are attributed to the $v(\mathrm{OH})$ vibrations of water molecules for compounds 1-4. The carboxylate groups for compounds $\mathrm{H}_{2}$ dipic and 1-4 exhibit strong carbonyl bands in the region of $1701-1456 \mathrm{~cm}^{-1}$.

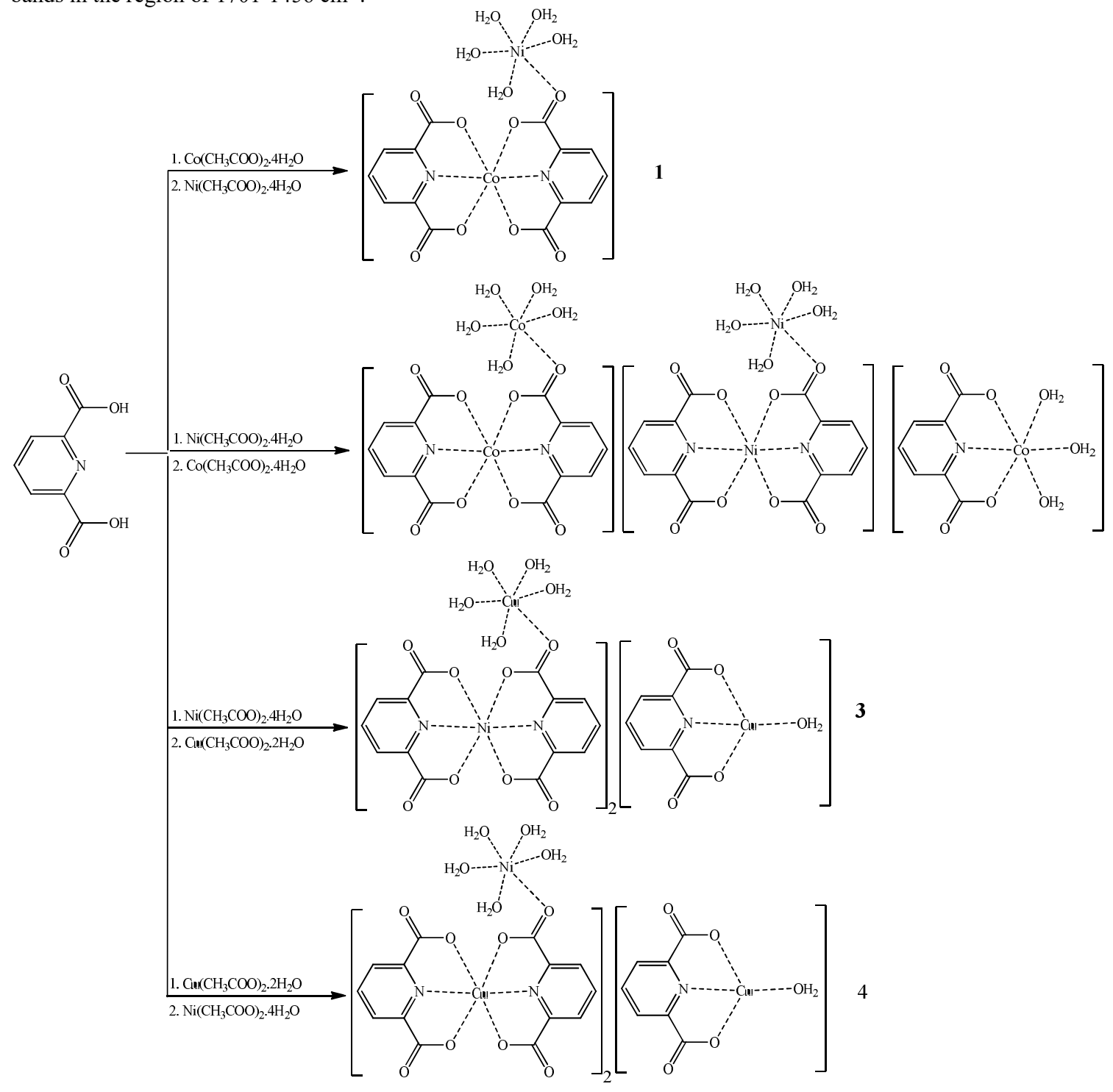

Figure 1. Syntheses of all compounds.

Bull. Chem. Soc. Ethiop. 2020, 34(2) 
These bands are reflected by IR spectrum of the asymmetric $\left(v_{\mathrm{as}}\right)$ and symmetric $\left(v_{\mathrm{s}}\right)$ stretching vibrations at 1701 and $1456 \mathrm{~cm}^{-1}$ for $\mathrm{H}_{2}$ dipic, 1615 and 1432,1606 and $1486 \mathrm{~cm}^{-1}$ for 1,1620 and 1452,1605 and $1487 \mathrm{~cm}^{-1}$ for 2,1615 and 1432,1606 and $1486 \mathrm{~cm}^{-1}$ for 3 , and 1620 and 1422,1605 and $1487 \mathrm{~cm}^{-1}$ for 4 . The differences $(\Delta v)$ between the asymmetric and symmetric stretches of the carboxylate groups of 183 and 120 for $\mathbf{1}, 168$ and 118 for 2,183 and 120 for $\mathbf{3}$ and 168 and 120 for $\mathbf{4}$ are which suggest monodentate and bridging, respectively, binding of the carboxylate group to the metal ion in all complexes [29]. The strong absorption bands in the region of $1595-1426 \mathrm{~cm}^{-1}$ are attributed to the $v(\mathrm{C}=\mathrm{N})$ and $v(\mathrm{C}=\mathrm{C})$ vibrations for all compounds. The $\mathrm{C}-\mathrm{O}$ vibrations data for all compounds between 1369 and $1060 \mathrm{~cm}^{-1}$ as expected. The ring wagging vibrations of the pyridine groups are also observed in the 801-706 $\mathrm{cm}^{-1}$ region for compounds $\mathrm{H}_{2}$ dipic and 1-4. The weak bands at $429-459 \mathrm{~cm}^{-1}$ and $595-551 \mathrm{~cm}^{-1}$ are from the $\mathrm{M}-\mathrm{N}$ and $\mathrm{M}-\mathrm{O}$ vibrations of the compounds 1-4 (Table 1).

Table 1. IR spectral data of $\mathbf{1 - 5}\left(\mathrm{cm}^{-1}\right)$.

\begin{tabular}{|c|c|c|c|c|c|}
\hline & $\mathrm{H}_{2}$ DPC & 1 & 2 & 3 & 4 \\
\hline$v(\mathrm{OH})$ & $2900(\mathrm{br})$ & 3474(br) & 3493(br) & 3474(br) & 3493(br) \\
\hline$v(\mathrm{C}-\mathrm{H})$ & $3069(w)$ & $3090(w)$ & 3085(w) & 3071(w) & $3080(w)$ \\
\hline$v(\mathrm{COO}) *$ & \multirow{2}{*}{$\begin{array}{l}1701(\mathrm{~s}) \\
1456(\mathrm{~s})\end{array}$} & $\begin{array}{l}1615(\mathrm{~s}) \\
1432(\mathrm{~s})\end{array}$ & $\begin{array}{l}1620(\mathrm{~s}) \\
1452(\mathrm{~s})\end{array}$ & $\begin{array}{l}1615(\mathrm{~s}) \\
1432(\mathrm{~s})\end{array}$ & $\begin{array}{l}1620(\mathrm{~s}) \\
1452(\mathrm{~s})\end{array}$ \\
\hline$v(\mathrm{COO})^{* *}$ & & $\begin{array}{l}1606(\mathrm{~s}) \\
1486(\mathrm{~s})\end{array}$ & $\begin{array}{l}1605(\mathrm{~s}) \\
1487(\mathrm{~s})\end{array}$ & $\begin{array}{l}1606(\mathrm{~s}) \\
1486(\mathrm{~s})\end{array}$ & $\begin{array}{l}1605(\mathrm{~s}) \\
1487(\mathrm{~s})\end{array}$ \\
\hline $\begin{array}{l}v(\mathrm{C}=\mathrm{N}) \\
v(\mathrm{C}=\mathrm{C})\end{array}$ & $\begin{array}{l}1574(\mathrm{~s}) \\
1415(\mathrm{~s})\end{array}$ & $\begin{array}{l}1595(\mathrm{~s}) \\
1577(\mathrm{~s}) \\
1563(\mathrm{~s}) \\
1432(\mathrm{~s}) \\
1429(\mathrm{~s})\end{array}$ & $\begin{array}{l}1590(\mathrm{~s}) \\
1587(\mathrm{~s}) \\
1533(\mathrm{~s}) \\
1452(\mathrm{~s}) \\
1426(\mathrm{~s})\end{array}$ & $\begin{array}{l}1595(\mathrm{~s}) \\
1577(\mathrm{~s}) \\
1563(\mathrm{~s}) \\
1432(\mathrm{~s}) \\
1429(\mathrm{~s})\end{array}$ & $\begin{array}{l}1590(\mathrm{~s}) \\
1587(\mathrm{~s}) \\
1533(\mathrm{~s}) \\
1452(\mathrm{~s}) \\
1426(\mathrm{~s})\end{array}$ \\
\hline$v(\mathrm{C}-\mathrm{O})$ & $\begin{array}{l}1333(\mathrm{~s}) \\
1299(\mathrm{~s}) \\
1080(\mathrm{~s}) \\
\end{array}$ & $\begin{array}{l}1369(\mathrm{~s}) \\
1284(\mathrm{~s}) \\
1074(\mathrm{~s}) \\
\end{array}$ & $\begin{array}{l}1359(\mathrm{~s}) \\
1274(\mathrm{~s}) \\
1070(\mathrm{~s}) \\
\end{array}$ & $\begin{array}{l}1360(\mathrm{~s}) \\
1280(\mathrm{~s}) \\
1060(\mathrm{~s}) \\
\end{array}$ & $\begin{array}{l}1359(\mathrm{~s}) \\
1274(\mathrm{~s}) \\
1085(\mathrm{~s}) \\
\end{array}$ \\
\hline$v($ py) & $782(\mathrm{~s})$ & $762(\mathrm{~s})$ & $752(\mathrm{~s})$ & $775(\mathrm{~s})$ & $760(\mathrm{~s})$ \\
\hline$v(\mathrm{Co}-\mathrm{O})$ & - & $551(\mathrm{~s})$ & $555(\mathrm{~s})$ & - & - \\
\hline$v(\mathrm{Co}-\mathrm{N})$ & - & 436(w) & 439(w) & - & - \\
\hline$v(\mathrm{Ni}-\mathrm{O})$ & - & $591(\mathrm{~s})$ & $595(\mathrm{~s})$ & 591(s) & $595(\mathrm{~s})$ \\
\hline$v(\mathrm{Ni}-\mathrm{N})$ & - & $459(w)$ & 442(w) & $438(w)$ & $429(\mathrm{w})$ \\
\hline$v(\mathrm{Co}-\mathrm{O})$ & - & - & - & $551(\mathrm{~s})$ & $555(\mathrm{~s})$ \\
\hline$v(\mathrm{Cu}-\mathrm{N})$ & - & - & - & 429(w) & $430(w)$ \\
\hline
\end{tabular}

Abbreviations: w, weak; m, medium; s, strong; b, broad.

Figures 2-5 show the TG-DTG and DTA curves of compounds 1-4, respectively, and thermal analyses results are given in Table 2. For all compounds (1-4), the first stage, an endothermic peak corresponds to the loss of water molecules, namely five moles for $\mathbf{1}$, thirteen moles for 2, eleven moles for $\mathbf{3}$, and eleven moles for $\mathbf{4}$. The exothermic second stage is consistent to the loss of dipic molecules, namely two moles for $\mathbf{1}$, five moles for $\mathbf{2}$, five moles for $\mathbf{3}$, and five moles for $\mathbf{4}$. The final decomposition products are $\mathrm{CoO}$ and $\mathrm{NiO}$ for $\mathbf{1}, \mathrm{CoO}$ and $\mathrm{NiO}$ for $\mathbf{2}, \mathrm{CuO}$ and $\mathrm{NiO}$ for $\mathbf{3}$, and $\mathrm{CuO}$ and $\mathrm{NiO}$ for $\mathbf{4}$, and they are identified by $\mathrm{IR}$ spectroscopy (Table 2).

The electronic spectra of compounds 1-4 and the free ligand $\mathrm{H}_{2}$ dipic were recorded in water and in DMSO solution with $1 \times 10^{-3} \mathrm{molL}^{-1}$ concentrationsat room temperature (Table 3, Figure 2). The characteristic $\pi-\pi *$ transitions in the spectrum of 1 are of $280 \mathrm{~nm}, 285 \mathrm{~nm}$ for $2,290 \mathrm{~nm}$ for 3,275 nm for 4 in water, and $289 \mathrm{~nm}$ for $\mathbf{1}, 280 \mathrm{~nm}$ for $\mathbf{2}, 279 \mathrm{~nm}$ for 3,269 nm for 4 in DMSO, and with the same profiles as the free ligand $\mathrm{H}_{2}$ dipic $(286 \mathrm{~nm}$ in water/ethanol and 297 $\mathrm{nm}$ in DMSO). The bands for the d-d transitions are observed at 750 and $760 \mathrm{~nm}$ for $\mathbf{1 ,} 761$ and 
$767 \mathrm{~nm}$ for $\mathbf{2 ,} 750$ and $765 \mathrm{~nm}$ for $\mathbf{3}$, and 750 and 765 for $\mathbf{4}$ in water and 770 and $790 \mathrm{~nm}$ for $\mathbf{1}$, 774 and $795 \mathrm{~nm}$ for 2, 740 and $760 \mathrm{~nm}$ for 3, and 745 and 775 for 4 in DMSO (Table 3).

Table 2. Thermal analyses results of compounds $\mathbf{2 - 5}$.

\begin{tabular}{|c|c|c|c|c|c|}
\hline Compound & Temperature $\left({ }^{\circ} \mathrm{C}\right)$ & $\mathrm{DTG}_{\max }\left({ }^{\circ} \mathrm{C}\right)$ & Leaving group & Found (\%) & Calculated (\%) \\
\hline \multirow{4}{*}{$\mathbf{1}$} & $30-175$ & 165 & $5 \mathrm{H}_{2} \mathrm{O}$ & 17.10 & 16.27 \\
\cline { 2 - 6 } & $175-450$ & $205,276,350$ & 2 dipic & 59.00 & 59.72 \\
\cline { 2 - 6 } & - & - & $\mathrm{Co}, \mathrm{Ni}$ & 23.90 & 24.01 \\
\hline \multirow{2}{*}{} & $30-200$ & 190 & $13 \mathrm{H}_{2} \mathrm{O}$ & 17.10 & 17.09 \\
\cline { 2 - 6 } & $200-500$ & $215,280,376$ & 5 dipic & 60.40 & 60.30 \\
\cline { 2 - 6 } & - & - & $\mathrm{Co}, \mathrm{Ni}$ & 22.50 & 22.61 \\
\hline \multirow{3}{*}{$\mathbf{3}$} & $30-180$ & 165 & $11 \mathrm{H}_{2} \mathrm{O}$ & 14.90 & 14.88 \\
\cline { 2 - 6 } & $180-550$ & $210,280,380$ & 5 dipic & 62.00 & 61.99 \\
\cline { 2 - 6 } & - & - & $\mathrm{Cu}, \mathrm{Ni}$ & 23.10 & 23.13 \\
\hline \multirow{4}{*}{$\mathbf{n y y y y y}$} & $30-155$ & 150 & $11 \mathrm{H}_{2} \mathrm{O}$ & 14.80 & 14.88 \\
\cline { 2 - 6 } & $185-600$ & $215,280,376$ & 5 dipic & 62.20 & 61.99 \\
\cline { 2 - 6 } & - & - & $\mathrm{Cu}, \mathrm{Ni}$ & 23.00 & 23.13 \\
\hline
\end{tabular}

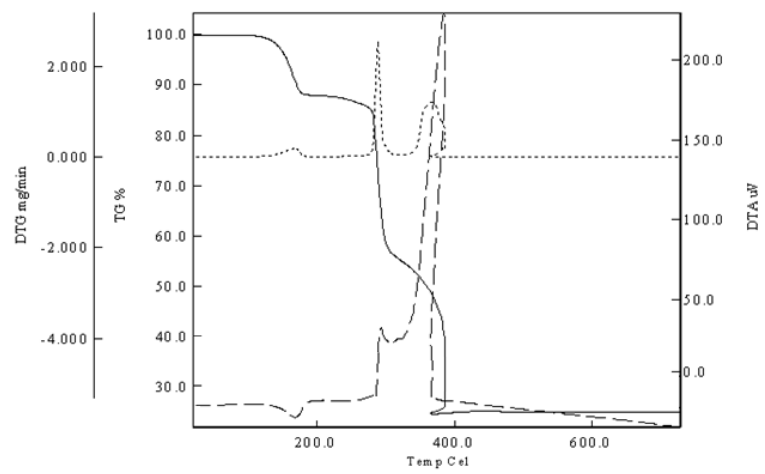

Figure 2. The TG-DTG and DTA curves of $\mathbf{1}$.

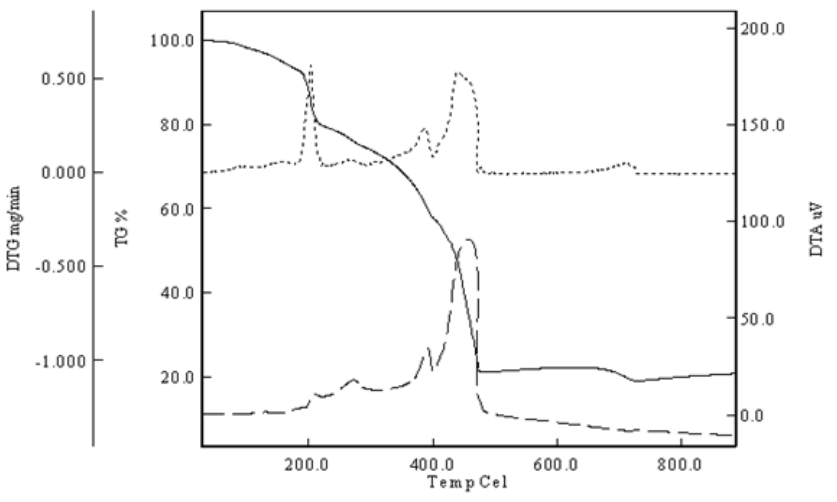

Figure 3. The TG-DTG and DTA curves of 2. 


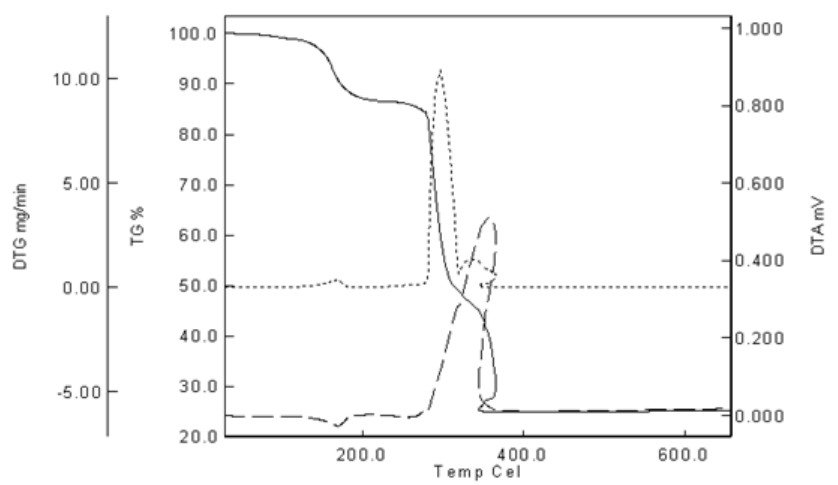

Figure 4. The TG-DTG and DTA curves of $\mathbf{3}$.

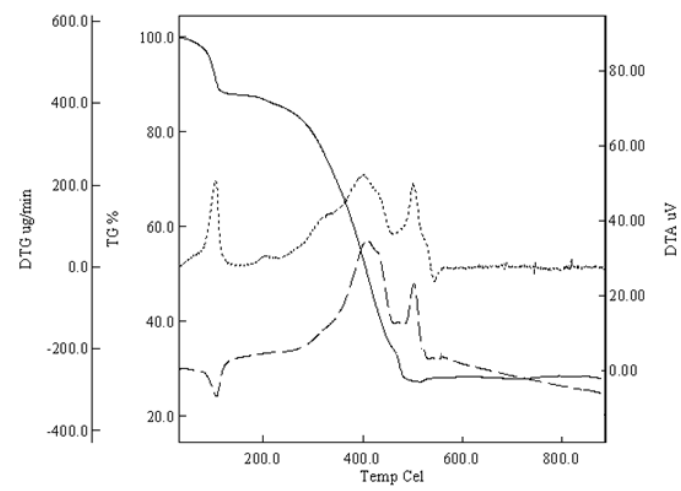

Figure 5. The TG-DTG and DTA curves of 4.

Table 3. Optical properties for all compounds in water and in DMSO $\left(\mathrm{nm}\left(\mathrm{Lmol}^{-1} \mathrm{~cm}^{-1}\right)\right.$.

\begin{tabular}{|c|c|c|c|c|c|}
\hline Compund & $\mathbf{H}_{\mathbf{2} \text { dipic }}$ & $\mathbf{1}$ & $\mathbf{2}$ & $\mathbf{3}$ & $\mathbf{4}$ \\
\hline Water & $286(19860)$ & $280(32050)$ & $285(31090)$ & $290(32050)$ & $275(31090)$ \\
& & $760(300)$ & $761(200)$ & $765(300)$ & $765(200)$ \\
& & $750(250)$ & $767(140)$ & $750(250)$ & $750(140)$ \\
\hline DMSO & $297(36160)$ & $289(32990)$ & $280(37380)$ & $279(32990)$ & $269(37380)$ \\
& & $790(200)$ & $795(400)$ & $760(200)$ & $775(400)$ \\
& & $770(150)$ & $774(100)$ & $740(150)$ & $745(100)$ \\
\hline
\end{tabular}

The room temperature magnetic moment of the metal complexes is of $5.94 \mathrm{BM}$ for $2,3.82$ $\mathrm{BM}$ for 3, 2.78 $\mathrm{BM}$ for 4 , and $4.85 \mathrm{BM}$ for 5 per metal ion, indicating the presence of five $\left(\mathrm{Fe}^{3+}\right.$, $\left.d^{5}\right)$, three $\left(\mathrm{Co}^{2+}, d^{7}\right)$, two $\left(\mathrm{Ni}^{2+}, d^{8}\right)$, and four $\left(\mathrm{Fe}^{2+}, d^{6}\right)$ unpaired electrons.

The molar conductivity data in water in DMSO are of $6.5 \Omega^{-1} \mathrm{~cm}^{2} \mathrm{~mol}^{-1}$ for $1,9.5 \Omega^{-1} \mathrm{~cm}^{2}$ $\mathrm{mol}^{-1}$ for $\mathbf{2}, 5.8 \Omega^{-1} \mathrm{~cm}^{2} \mathrm{~mol}^{-1}$ for 3 , and $3.2 \Omega^{-1} \mathrm{~cm}^{2} \mathrm{~mol}^{-1}$ for $\mathbf{4}$, indicating that the complexes 1-4 are non-ionic complex [30]. 


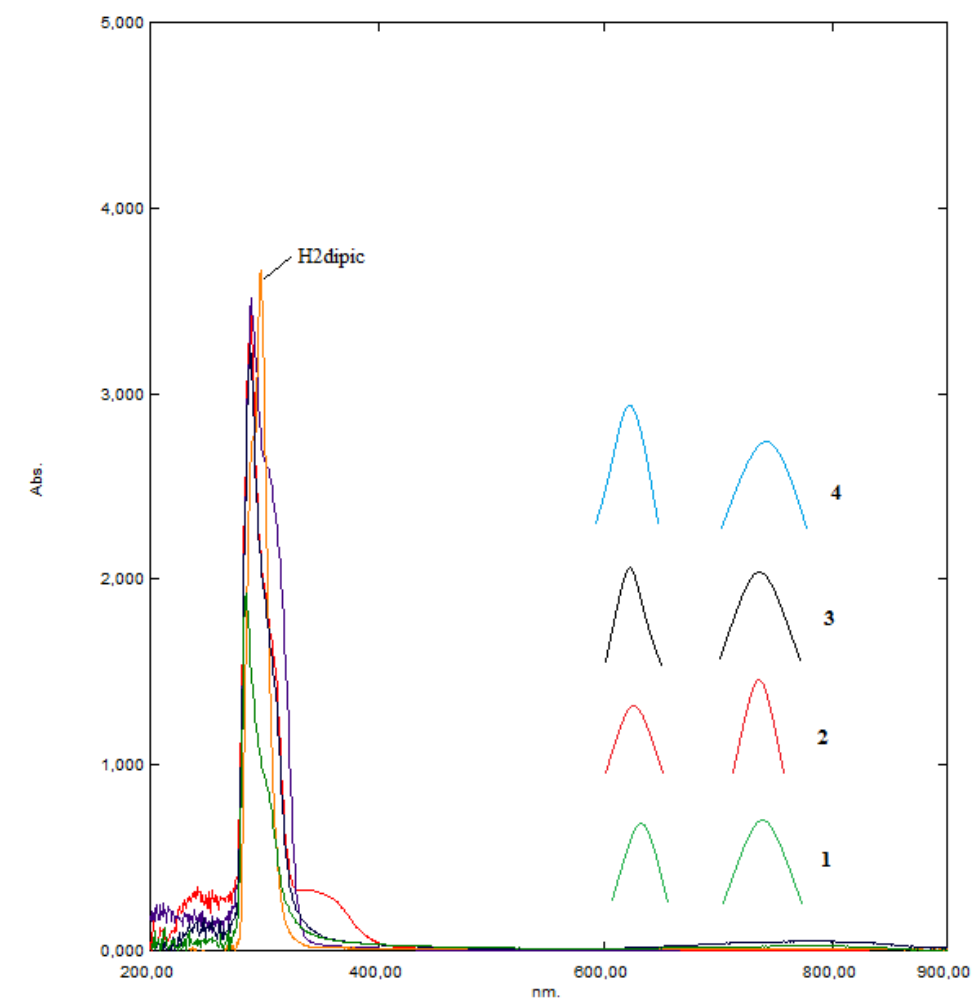

Figure 2. UV-Vis spectra of compounds all compounds in DMSO.

\section{CONCLUSION}

In the present work, four newly compounds (1-4) were prepared for the first time. The structures of 1-4 might be proposed as octahedral ([Cu(dipic) $\left.\left(\mathrm{H}_{2} \mathrm{O}\right)\right]$ unit for 2 square plane) according to results of elemental, spectral, thermal analyses, magnetic measurement and molar conductivity.

\section{REFERENCES}

1. Aghabozorg, H.; Manteghi, F.; Sheshmani, S. A brief review on structural concepts of novel supramolecular proton transfer compounds and their metal complexes. J. Iran. Chem. Soc. 2008, 5, 184-227.

2. Hoof, D.L.; Tisley, D.G.; Walton, R.A. Studies on metal carboxylates. Part III. Pyridine-2,6dicarboxylates of the lanthanides. Synthesis and spectral studies and the X-ray photoelectron spectra of several pyridine carboxylate complexes. J Chem. Soc. Dalton Trans. 1973, 2, 200204.

3. Yang, L.; Crans, D.C.; Miller, S.M.; La Cour, A.; Anderson, O.P.; Kaszynski, P.M.; Godzala, III, M.E.; Austin, L.D.; Willsky, G.R. Cobalt(II) and cobalt(III) dipicolinate 
complexes: Solid state, solution, and in vivo insulin-like properties. Inorg. Chem. 2002, 41, 4859-4871.

4. Buglyo', P.; Crans, DC.; Nagy, EM.; Lindo, RL.; Yang, L.; Smee, J.J.; Jin, W.; Chi, L.H.; Godzala, III, M.E.; Willsky, G.R. Aqueous chemistry of the vanadium ${ }^{\mathrm{III}}\left(\mathrm{V}^{\mathrm{III}}\right)$ and the $\mathrm{V}^{\mathrm{III}}$ dipicolinate systems and a comparison of the effect of three oxidation states of vanadium compounds on diabetic hyperglycemia in rats. Inorg. Chem. 2005, 44, 5416-5427.

5. Yenikaya, C.; Büyükkıdan, N.; Sarı, M.; Keşli, R.; İlkimen, H.; Bülbül, M.; Büyükgüngör, O. Synthesis, characterization and biological evaluation of novel $\mathrm{Cu}(\mathrm{II})$ complexes with proton transfer salt of 2,6-pyridinedicarboxylic acid and 2-amino-4-methylpyridine. $J$. Coord. Chem. 2011, 64, 3353-3365.

6. Yenikaya, C.; Poyraz, M.; Sarı, M.; Demirci, F.; İlkimen, H.; Büyükgüngör, O. Synthesis, characterization and biological evaluation of a novel $\mathrm{Cu}$ (II) complex with the mixed ligands 2,6-pyridinedicarboxylicacid and 2-aminopyridine. Polyhedron 2009, 28, 3526-3532.

7. İlkimen, H.; Yenikaya, C.; Sarı, M.; Bülbül, M.; Tunca, E.; Süzen, Y. Synthesis and characterization of a proton transfer salt between dipicolinic acid and 2-amino-6methylbenzothiazole and its complexes, and their inhibition studies on carbonic anhydrase isoenzymes. Polyhedron 2013, 61, 56-64.

8. İlkimen, H.; Yenikaya, C.; Sarı, M.; Bülbül, M.; Tunca, E.; Dal, H. Synthesis and characterization of a proton transfer salt between 2,6-pyridinedicarboxylic acid and 2aminobenzothiazole, and its complexes and their inhibition studies on carbonic anhydrase isoenzymes. J. Enzyme Inhib. Med. Chem. 2014, 29, 353-361.

9. İlkimen, H.; Yenikaya, C.; Sarı, M.; Bülbül, M.; Tunca, E.; Dal, H.; Bas, M. Synthesis and characterization of complexes of a novel proton transfer salt and their inhibition studies on carbonic anhydrase isoenzymes. J. Enzyme Inhib. Med. Chem. 2014, 30, 195-203.

10. İlkimen, H.; Yenikaya, C.; Gülbandılar, A.; Sarı, M. Synthesis and characterization of a novel proton salt of 2-amino-6-nitrobenzothiazole with 2,6-pyridinedicarboxylic acid and its metal complexes and their antimicrobial and antifungal activity studies. J. Mol. Struct. 2016, 1120, 25-33.

11. Büyükkıdan, N.; Yenikaya, C.; İlkimen, H.; Karahan, C.; Darcan, C.; Şahin, E. Synthesis, characterization and antimicrobial activity of a novel proton salt and its $\mathrm{Cu}(\mathrm{II})$ complex. Russian J. Coord. Chem. 2013, 39, 96-103.

12. Nathan, L.C.; Mai, T.D. Influence of the spectator cation on the structure of anionic pyridine-2,6-dicarboxylato complexes of cobalt(II), nickel(II), and copper(II). J. Chem. Cryst. 2000, 30, 509-518.

13. Eshtiagh-Hosseini, H.; Yousefi, Z.; Shafiee, M.; Mirzaei, M. Fe(III) and cobalt(II) coordination compounds of 5-bromo-6-methyl-2-morpholinepyrimidinium-4-amine pyridine-2,6-dicarboxylate. J. Coord. Chem. 2010, 63, 3187-3197.

14. Datta, A.; Hwang, W.S.; Revaprasadu, N. One new carboxylato-bridged dimeric network of Co(II): Synthesis and structural aspects. Bulgarian Chem. Com. 2009, 41, 261-265.

15. Liu, Y. Magnetic properties of a pyridine-2,6-dicarboxylate bridged dinuclearcobalt(II) complex. Fenzi Kexue Xuebao 2009, 25, 69-71.

16. Xie, L.; Wei, Y.; Wang, Y.; Hou, H.; Fan, Y.; Zhu, Y. 2D and 3D binuclear cobalt supramolecular complexes: Synthesis and crystal structures. J. Mol. Struct. 2004, 692, 201207.

17. Qi, Y.; Wang, Y.; Fan, H.; Cao, M.; Mao, L.; Hu, C.; Wang, E.; Hu, N.; Jia, H. Structure characterization and physical properties of a complex with supramolecular architectures $\mathrm{Co}(2,6-\mathrm{DPC})_{2} \mathrm{Co}\left(\mathrm{H}_{2} \mathrm{O}\right)_{5} \cdot 2 \mathrm{H}_{2} \mathrm{O}(\mathrm{DPC}=2,6$-pyridinedicarboxylate $) . J$. Mol. Struct. 2004, 694, 73-78.

18. Wang, L.; Duan, L.; Wang, E.; Xiao, D.; Li, Y.; Lan, Y.; Xu, L.; Hu, C. Novel hydrogenbonded three-dimensional network complexes containing cobalt-pyridine-2,6-dicarboxylic acid. Trans. Metal Chem. 2004, 29, 212-215. 
19. Jiang, Y.M.; Wang, X.L.; Yin, X. Synthesis and crystal structure of bridging binuclear complex $\left[\mathrm{Co}(\mathrm{DPC})_{2} \mathrm{Co}\left(\mathrm{H}_{2} \mathrm{O}\right)_{5}\right] \cdot 2 \mathrm{H}_{2} \mathrm{O}$. Wuji Huaxue Xuebao 2004, 20, 175-177.

20. Siddiqi, Z.A. Ansari, I.A.; Sama, F.; Shahid, M. Synthesis and characterization of a carboxylate bridged homodinuclearCo(II) complex: Crystal structure of $\left[\mathrm{Co}_{2}(\mathrm{Pda})_{2}\left(\mathrm{H}_{2} \mathrm{O}\right)_{5}\right] \cdot 2 \mathrm{H}_{2} \mathrm{O}\left(\mathrm{H}_{2} \mathrm{Pda}=\right.$ pyridine-2,6-dicorboxylic acid). Int. J. Innov. Res. Sci. Eng. Tech. 2014, 3, 8673-8679.

21. Wen, Y.H.; Li, Z.J.; Qin, Y.Y.; Kang, Y. Chen, Y.B.; Cheng, J.K.; Yao, Y.G. Pentaaqua(mpyridine-2,6-dicarboxylato-N,O,O', $\left.\mathrm{O}^{\prime \prime}\right)$ (pyridine-2,6-dicarboxylato-N,O,O")dinickel(II) dehydrate. Acta Cryst. 2002, E58, m762-m764.

22. Wang, L.; Duan, L.; Xiao, D.; Wang, E.; Hu, C. Synthesis of novel copper compounds containing isonicotinic acid and/or 2,6-pyridinedicarboxylic acid: Third-order nonlinear optical properties. J. Coord. Chem. 2004, 57, 1079-1087.

23. Yue, C.; Lin, Z.; Chen, L.; Jiang, F.; Hong, M. The 2D-3D networks with infinite channels or difform chains of copper(II) complexes via weak non-covalent interactions. J. Mol. Struct. 2005, 779, 16-22.

24. Kirillova, M.V.; Kirillov, A.M.; Guedes da Silva, M.F.C.; Kopylovich, M.N.; Frausto da Silva, J.J.R.; Pombeiro, A.J.L. Three-dimensional hydrogen bonded metal-organic frameworks constructed from $\left[\mathrm{M}\left(\mathrm{H}_{2} \mathrm{O}\right)_{6}\right]\left[\mathrm{M}^{\prime}(\text { dipicolinate })_{2}\right] \cdot \mathrm{mH}_{2} \mathrm{O}\left(\mathrm{M} / \mathrm{M}^{\prime}=\mathrm{Zn} / \mathrm{Ni}\right.$ or Ni/Ni). Identification of intercalated acyclic $\left(\mathrm{H}_{2} \mathrm{O}\right)_{6} /\left(\mathrm{H}_{2} \mathrm{O}\right)_{10}$ clusters. Inorg. Chim. Acta 2008, 361, 1728-1737.

25. Parent, A.R.; Vedachalam, S.; Landee, C.P.; Turnbull, M.M. Syntheses, crystal structures and magnetic properties of heteronuclear bimetallic compounds of $\left[\mathrm{Cu}(\mathrm{pdc})_{2}\right]\left[\mathrm{M}\left(\mathrm{H}_{2} \mathrm{O}\right)_{5}\right] \cdot 2 \mathrm{H}_{2} \mathrm{O}[\mathrm{M}=\mathrm{Ni}(\mathrm{II}), \mathrm{Co}(\mathrm{II}), \mathrm{Mn}(\mathrm{II})$; pdc = 2,6-pyridinedicarboxylato $]$. J. Coord. Chem. 2008, 61, 93-108.

26. Kirillova, M.V.; Guedes da Silva, M.F.C.; Kopylovich, M.N.; Frausto da Silva, J.J.R.; Pombeiro, A.J.L. 3D hydrogen bonded heteronuclear $\mathrm{Co}^{\mathrm{II}}, \mathrm{Ni}^{\mathrm{II}}, \mathrm{Cu}^{\mathrm{II}}$ and $\mathrm{Zn}^{\mathrm{II}}$ aqua complexes derived from dipicolinic acid. Inorg. Chim. Acta 2007, 360, 506-512.

27. Yesilel, O.Z.; Ilker, I.; Refat, M.S.; Ishida, H. Syntheses and characterization of two copper pyridine-dicarboxylate compounds containing water clusters. Polyhedron 2010, 29, 2345 2351.

28. $\mathrm{Wu}$, J. Synthesis, characterization and crystal structure of a 3-D supramolecular $\mathrm{Cu} / \mathrm{Mn}$ complex with pydc. Cryst. Res. Tech. 2008, 43, 1097-1100.

29. Nakamoto, K.; Infrared and raman spectra of inorganic and coordination compounds. 5th ed., Wiley-Interscience: NewYork; 1997; p 232.

30. Geary, W.J. The use of conductivity measurements in organic solvents for the characterisation of coordination compounds. Coord. Chem. Rev. 1971, 7, 81-122. 